\title{
ANALISIS PENGARUH RETURN OF ASSET DAN CAPITAL ADEQUACY RATIO TERHADAP KINERJA KEUANGAN PADA PERUSAHAAN PERBANKAN DI INDONESIA
}

\author{
Hendri Setyawan ${ }^{1}$, Saprudin ${ }^{2}$ \\ Sekolah Tinggi Ilmu Ekonomi Jayakarta \\ Jakarta, Indonesia \\ hendrysn1@gmail.com, saprudinmaksudi@gmail.com
}

\begin{abstract}
ABSTRAK
Bank merupakan suatu lembaga yang berperan sebagai perantara keuangan (financial intermediary) antara pihak-pihak yang memiliki dana (surplus unit) dengan pihak-pihak yang memerlukan dana (deficit unit), serta sebagai lembaga yang berfungsi memperlancar aliran lalu lintas pembayaran. Dengan demikian, kegiatan utama adalah menghimpun dana dari masyarakat dan menyalurkannya kembali kepada masyarakat guna meningkatkan kesejahteraan masyarakat. Tujuan penelitian ini adalah untuk mengetahui apakah ada pengaruh signifikan dari Return on Asset (ROA), Capital Adequacy Ratio (CAR) terhadap Net Profit Margin (NPM) perbankan yang terdaftar di Bursa Efek Indonesia (BEI). Sampel yang digunakan adalah 5 bank yang terdaftar di BEI. Penelitian ini menggunakan analisa regresi linier berganda dengan menggunakan sofware SPSS for Windows 24,00. Hasil penelitian menjelaskan bahwa Rerurn on Asset mempunyai pengaruh signifikan terhadap Net Profit Margin, sedangkan Capital Adequacy Ratio mempunyai pengaruh terhadap Net Profit Margin dengan arah negatif pada lima bank yang terdaftar di BEI.
\end{abstract}

Kata kunci : Return on Asset, Capital Adequacy Ratio, Net Profit margin.

\section{PENDAHULUAN}

Bank merupakan badan usaha yang menghimpun dana dari masyarakat dalam bentuk simpanan dan menyalurkan kepada masyarakat dalam bentuk kredit atau bentuk-bentuk lainnya dalam rangka meningkatkan taraf hidup masyarakat. Kegiatan perbankan harus mampu menjaga keamanan dana masyarakat, menjaga kesehatan bank, dan perkembangan usaha yang baik serta mampu memberikan sumbangan yang berarti terhadap perkembangan perekonomian nasional, hal tersebut hanya mungkin dilaksanakan apabila bank mampu menjaga kinerjanya dengan baik terutama tingkat likuiditas, solvabilitas, dan profitabilitas.
Setiap perusahaan termasuk bank mempunyai tujuan usaha yaitu mendapatkan keuntungan. Untuk mendapatkan keuntungan yang maksimal bank bisa menggunakanan analisis rasio-rasio keuangan bank untuk menentukan kebijakan terbaik demi mendapatkan keuntungan maksimal.

Metode yang paling sering digunakan untuk mengukur kinerja keuangan adalah financial ratio yang dianalisis dari laporan keuangan perusahaan. Beberapa rasio yang sering digunakan oleh investor dalam menilai kinerja perusahaan adalah rasio profitabilitas yang terdiri dari Return on Asset (ROA), Net Provit Margin (NPM), Capital Adecuency Ratio (CAR), Rasio Biaya Operasional terhadap 
Pendapatan Operasional (BOPO), Net Profit Margin (NPM) dan Earning per Share (EPS) dan lain sebagainya.

Pada tahun 2008 terjadi krisis global yang mengakibatkan adanya fenomena manajemen laba yang berdampak di Indonesia yaitu kasus Bank Century bahwa bank tersebut mengalami kesulitan likuiditas karena mengalami kliring akibat adanya penarikan dana besar yang dilakukan nasabah potensial. Kalah kliring yang menimbulkan antrian panjang nasabah yang kesulitan mencairkan uangnya ini juga tersiar ke publik hingga menimbulkan negative signalment. Indikasi ketidaksehatan Bank Century dimulai sejak tahun 2003, krisis tahun 2008 memicu Capital Adequacy Ratio (CAR) bank tersebut menjadi negatif $3,53 \%$. Hal ini dapat kita lihat pada sejarah laporan keuangan bank tersebut.

Pada tahun 2003 dan 2004, Bank Century menduduki posisi Non Performing Loan (NPL) terburuk yaitu 19,77\% (2003) dan 13,37 \% (2004), meskipun pada tahun-tahun berikutnya NPL bank Century membaik. Pada tahun 2004, Bank Century membukukan tingkat CAR terendah di antara bank lain yaitu 9,44. Pada tahun 2005, CAR Bank Century justru menurun hingga 8,08\%. Pada tahun 2006 mengalami peningkatan hingga $11,38 \%$ namun tetap merupakan CAR terendah diantara bank-bank lain. Pada tahun 2005, 2006 dan 2007, Bank Century juga membukukan tingkat Loan to Deposit Ratio (LDR) terendah yaitu masing-masing hanya 23,84 $\%, \quad 21,35 \%$, dan 36,39\% (www.bi.go.id).

\section{TINJAUAN PUSTAKA}

Modal bank secara singkat sebagaimana didefiniskan oleh Taswan (2013: 139) adalah dana yang diinvestasikan pemilik dalam rangka pendirian badan usaha yang dimaksudkan untuk membiayai kegiatan usaha bank selain juga untuk memenuhi regulasi yang telah ditetapkan oleh otoritas moneter. Dalam praktiknya, modal terdiri dari dua macam, yaitu modal inti dan modal pelengkap. Modal inti merupakan modal sendiri yang tertera dalam posisi ekuitas, sedangkan modal pelengkap merupakan modal pinjaman dan cadangan revaluasi aktiva serta cadangan penyisihan penghapusan aktiva produktif. Menurut Malayu Hasibuan (2015: 62) seuasi Surat Edaran Bank Indonesia No.23/67/Kep/Dir pasal 3 ayat (1), komponen modal bank modal inti dan modal pelengkap. Dalam PSAK No. 1 (2015: 1), "Laporan keuangan adalah penyajian terstruktur dari posisi keuangan dan kinerja keuangan suatu entitas". Laporan ini menampilkan sejarah entitas yang dikuantifikasi dalam nilai moneter."

Menurut Hery (2014: 113), "analisis laporan keuangan merupakan suatu proses untuk membedah laporan keuangan ke dalam unnsur-unsurnya dan menelaah masing-masing dari unsur tersebut dengan tunjuan memperoleh pengertian dan pemahaman yang baik dan tepat 
atas laporan keuangan itu sendiri." Menurut Kasmir (2016: 104), "Analisis rasio keuangan adalah Kegiatan membandingkan angka-angka yang ada dalam laporan keuangan dengan cara membagi satu angka dengan angka lainnya.“

Menurut Arief dan Edi (2016: 53), apabila dilihat dari sumber dari mana rasio ini dibuat, maka dapat digolongkan dalam tiga golongan, yaitu:

a. Rasio neraca (Balance Sheet Ratios), yang digolongkan dalam katagori ini adalah semua data yag diambil dari atau bersumber dari neraca.

b. Rasio-rasio laporan laba rugi (Income Statement Ratios), yang tergolong dalam katagori ini adalah semua data yang diambil dari laba rugi.

c. Rasio-rasio antar laporan (Interstatement Ratios), yang tergolong dalam katagori ini adalah semua data yang diambil dari neraca dan laporan laba rugi.

Menurut Kasmir (2016:

110), "Rasio likuiditas adalah rasio yang menunjukkan kemampuan perusahaan untuk membayar utang-utang (kewajiban) jangka pendeknnya yang jatuh tempo atau rasio untuk mengetahui kemampuan perusahaan dalam membiayai dan memenuhi kewajiban (utang) pada saat ditagih."

Menurut Kasmir (2016: 196), "Rasio profitabilitas merupakan rasio untuk menilai kemampuan perusahaan dalam mencari keuntungan." Rasio ini dapat juga memberikan ukuran tingkat efektivitas manajemen suatu perusahaan. Hal ini ditunjukkan oleh adanya laba yang dihasilkan dari penjuaan dan pendapatan investasi. Inti dari penggunaan rasio ini adalah untuk menunjukkan efisiensi perusahaan.

Menurut Munawir (2015:

33), "Rentabilitas atau profitability adalah menunjukkan kemampuan perusahaan untuk menghasilkan laba selama periode tertentu. Rentabilitas suatu perusahaan diukur dengan kesuksesan perusahaan dan kemampuan menggunakan aktivanya secara produktif, dengan demikian rentabilitas suatu perusahaan dapat diketahui dengan memperbandingkan antara laba yang diperoleh dalam suatu periode dengan jumlah aktiva atau jumlah modal perusahaan tersebut."

Menurut Irham Fahmi (2014: 79) "Rasio ini mengukur efektivitas manajemen secara keseluruhan yang ditujukan oleh besar kecilnya tingkat keuntungan yang diperoleh dalam hubungannya dengan penjualan maupun investasi."

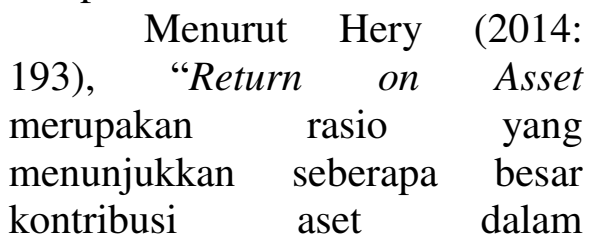
menciptakan laba bersih." Dengan kata lain, rasio ini digunakan untuk mengukur seberapa besar jumlah laba bersih yang akan dihasilkan dari setiap rupiah dana yang tertanam dalam total aset. Rasio ini dihitung dengan membagi laba bersih terhadap total aset.

Semakin tinggi hasil pengembalian atas aset berarti semakin tinggi juga jumlah laba 
bersih yang dihasilkan dari setia rupiah dana yang tertanam dalam total aset. Sebaliknya, semakin rendah hasil pengembalian atas aset berarti semakin rendah pula jumlah laba bersih yang dihasilkan dari setiap rupiah dana yang tertanam dalam total aset. ROA dapat dirumuskan sebagai berikut:

$$
R O A=\frac{\text { Laba Bersih Setelah Pajak }}{\text { Total Aset }} \times 100 \%
$$

ROA merupakan rasio pengukuran profitabilitas yang sering digunakan oleh manajer keuangan untuk mengukur efektifitas keseluruhan dalam menghasilkan laba dengan aktiva yang tersedia. Berdasarkan hal ini, maka faktor yang mempengaruhi profitabilitas adalah laba bersih setelah pajak, penjualan bersih dan total aset.

Menurut Bank Indonesia (Nomor 9/13/PBI/2007), CAR adalah penyediaan modal minimum bagi bank didasarkan pada risiko aktiva dalam arti luas, baik aktiva yang tercantum dalam neraca maupun aktiva yang bersifat administratif sebagaimana tercermin pada kewajiban yang masih bersifat kontijen dan/atau komitmen yang disediakan oleh bank bagi pihak ketiga maupun risiko pasar. Dalam mencari CAR ada Aktiva Tertimbang Menurut Risiko, dimana Aktiva yang memiliki bobot risiko paling besar adalah Kredit, Kredit juga memberikan kontribusi pendapatan yang paling besar bagi Bank. Artinya jika Kredit naik maka pendapatan bank akan naik, berarti ROE dan atau ROA akan naik. Dengan naiknya Kredit berarti akan menaikan total
ATMR, yang berarti juga akan menurunkan CAR. Nah atas dasar pemikiran itulah maka yang benar adalah bahwa jika CAR naik maka ROE dan atau ROA akan turun, demikian pula jika terjadi sebaliknya. Namun demikian Aktiva lainnya yang memiliki bobot risiko $100 \%$ adalah Fixed Assets dan Aset-aset lainya yang tidak memberikan kontribusi pendapatan bagi bank, jadi jika kenaikan ATMR karena diakibatkan oleh kenaikan aset pada kelompok ini maka dapat dibenarkan bahwa jika CAR naik maka ROE dan atau ROA akan naik demikian pula jika CAR turun maka ROE dan atau ROA akan turun karena penggunaan dana bank yang tidak memberikan kontribusi pendapatan operasional bank.

Maka dapat disimpulkan bahwa CAR adalah rasio kinerja bank untuk mengukur kecukupan modal yang dimiliki bank untuk menunjang aktiva yang mengandung atau menghasilkan risiko, seperti kredit yang diberikan kepada nasabah.

Menurut Malayu (2014: 65) CAR dapat dirumuskan berikut:

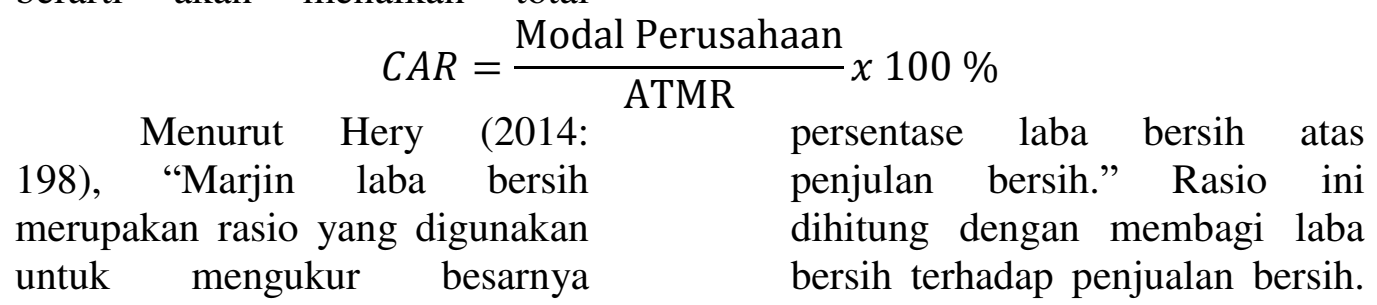


Laba bersih dihitung sebagai hasil pengurangan antara laba sebelum pajak penghasilan dengan beban pajak penghasilan. Yang dimaksud dengan laba sebelum pajak penghasilan di sini adalah laba operasional ditambah pendapatan dan keuntungan lainlain, lalu dikurangi dengan beban dan kerugian lain-lain.

Semakin tinggi marjin laba bersih berarti semakin tinggi pula laba bersih yang dihasilkan dari penjualan bersih. Hal ini disebabkan karena tingginya laba sebelum pajak penghasilan. Sebaliknya, semakin rendah marjin laba bersih berarti senakin rendah pula laba bersih yang dihasilkan dari penjualan. Hal ini dapat disebabkan karena rendahnya laba sebelum pajak penghasilan.

Secara matematis Net Profit Margin dapat dirumuskan sebagai

berikut:

$$
N P M=\frac{\text { Laba Besih Setelah Pajak }}{\text { Total Penjualan }} \times 100 \%
$$

Tujuan dan Manfaat Rasio Profitabilitas tidak hanya bagi pihak internal, tetapi juga bagi pihak ekternal atau di luar perusahaan, terutama pihakpihak yang memiliki kepentingan dengan perusahaan.

Tujuan penggunaan rasio profitabilitas menurut Kasmir (2016: 197), adalah:

a) Untuk mengukur atau menghitung laba yang diperoleh perusahaan dalam satu periode tertentu.

b) Untuk menilai posisi laba Perusahaan tahun sebelumnya dengan tahun sekarang.

c) Untuk menilai perkembangan laba dari waktu ke waktu.

d) Untuk menilai besarnya laba bersih sesudah pajak dengan modal sendiri.

e) Untuk mengukur produktivitas seluruh dana perusahaan yang digunakan baik modal pinjaman maupun modal sendiri.

f) Untuk mengukur produktivitas dari seluruh dana perusahaan yang digunakan baik modal sendiri.
Manfaat yang diperoleh rasio profitabilitas menurut Kasmir (2016:198), yaitu:

a) Mengetahui besarnya tingkat laba yang diperoleh perusahaan dalam satu periode.

b) Mengetahui posisi laba perusahaan tahun sebelumnya dengan tahun sekarang.

c) Mengetahui perkembangan laba dari waktu ke waktu.

d) Mengtahui besarnya laba bersih sesudah pajak dengan modal sendiri.

e) Mengetahui produktivitas dari seluruh dana perusahaan yang digunakan baik modal pinjaman maupun modal sendiri.

f) Manfaat lainnya.

$$
\text { Rismon Hamdi dan }
$$

Henny Setyo Lestary (2015), NPM, LDR, GDP dan inflation rate memiliki pengaruh yang signifikan terhadap ROA. Adapun dalam penelitian Agung Sugiarto (2012) dalam penelitiannya, variabel independen ukuran perusahaan, 
primary ratio, capital adequacy ratio (CAR) berpengaruh positif dan tidak signifikan terhadap kinerja bank. Sedangkan resiko kredit (CRR), beban operasional dan pendapatan operasional dan likuiditas memiliki pengaruh negatif dan tidak signifikan terhadap kinerja bank. Hasil penelitian Nurul Hidayati (2013) dari tingkat rasio profitabilitas, ditinjau dari return on asset, return on equity serta net profit margin menunjukkan bahwa bank tersebut memiliki kinerja yang baik. Dan dari tingkat rasio solvabilitas yang ditinjau dari primary ratio, capital ratio dan
CAR menunjukkan kedua bank tersebut memiliki kinerja yang baik pula.

$$
\text { Menurut Sugiyono }
$$
(2014: 93) mengemukakan bahwa kerangka pemikiran "merupakan model konseptual tentang bagaimana teori berhubungan dengan berbagai faktor yang telah diidentifikasi sebagai masalah yang penting". Berdasarkan teori masingmasing variabel penelitian, hubungan antarvariabel, dan penelitian terdahulu, berikut ini adalah kerangka pemikiran yang digunakan dalam penelitian ini:

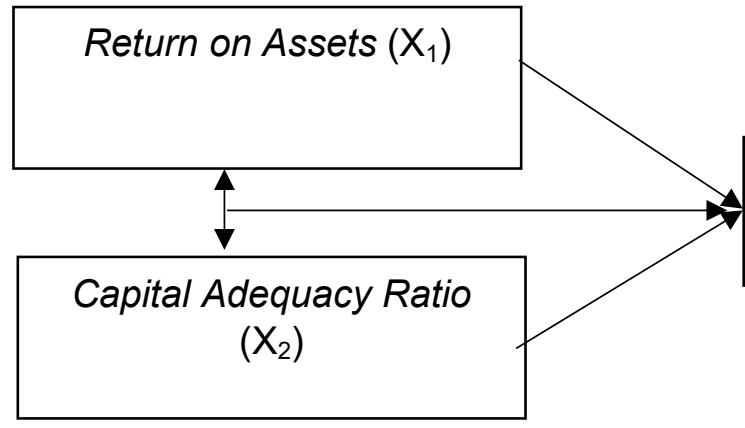

Berdasarkan gambar

Paradigma penelitian di atas, dapat dijelaskan bahwa variabel bebas (independen) dalam penelitian ini adalah Return on Assets (ROA) sebagai $\mathrm{X}_{1}$, Capital Adequacy Ratio (CAR) sebagai $\mathrm{X}_{2}$ dan Kinerja Keuangan sebagai Y baik secara parsial maupun simultan.

$$
\text { Menurut Sofar Silaen }
$$

(2018: 63), "Hipotesis adalah jawaban yang masih bersifar sementara terhadap permasalahan penelitian, secara teoritis dianggap paling tinggi tingkat kebenarannya, dan perlu dibuktikan melalui penelitian dan hasil penelitian dapat
Kinerja Keuangan (Y)

menolak atau menerima hipotesis tersebut." Dengan perkataan lain, hipotesis adalah pernyataan bersifat tafsiran/terkaan/prediksi dari hubungan antarvariabel yang diterima secara sementara sebagai suatau kebenaran.

Hipotesis penelitian ini adalah sebagai berikut :

$\mathrm{H}_{\mathrm{a}}$ :Diduga Return on Asset (ROA) secara parsial berpengaruh terhadap Net Profit Margin (NPM).

$\mathrm{H}_{\mathrm{a}}$ :Diduga Capital Adequacy Ratio (CAR) secara parsial tidak terhadap Net Profit Margin (NPM). 
$\mathrm{H}_{\mathrm{a}}$ :Diduga Return on Asset (ROA) dan Capital Adequacy Ratio (CAR) secara simultan tidak berpengaruh terhadap $\mathrm{Net}$ Profit Margin (NPM).

\section{METODE PENELITIAN}

Berdasarkan dari sifat data yang digunakan pada penelitian ini maka penelitian ini adalah jenis penelitian kuantitatif. Yaitu metodologi kuantitatif sebagai prosedur penelitian yang menghasilkan data berupa angkaangka dan umumnya dianalisis dengan menggunakan statistik/deskriptif atau inferensial. Statistika/deskriptif adalah metode-metode yang berkaitan dengan pengumpulan dan penyajian suatu gugus data sehingga memberikan informasi yang berguna. Pengklasifikasian menjadi statistika deskriptif dan statistika inferensia dilakukan berdasarkan aktivitas yang dilakukan.

Menutut Sugiyono (2016: 11), "Penelitian deskriftif adalah penelitian yang dilakukan untuk mengetahui nilai variabel baik satu variabel atau lebih (independent) tanpa membuat pembandingan atau hubungan dengan variabel lain." Sedangkan menurut Sofar Silaen (2018: 19), "Penelitian deskriftif adalah penelitian yang bertujuan untuk memberikan deskriptif, gambaran mengenai fakta-fakta, sifar-sifat, serta hubungan antar fenomena yang diteliti, termasuk hubungan kegiatan-kegiatan, sikap-sikap, pandangan-pandangan, serta proses-proses yang sedang berlangsung dan pengaruh- pengaruh dari suatu fenomena, atau untuk menentukan frekuensi distribusi suatu gejala atau frekuensi adanya hubungan tertentu antara suatu gejala dengan gejala lain.

Peneliti menggunakan penelitian berupa laporan keuangan pada perusahaan perbankan di indonesia meliputi laporan rasio Return on Assets, Capital Adequacy Ratio dan Net Profit Margin pada perusahaan perbankan di indonesia yang terdaftar di Bursa Efek Indonesia (BEI) dari periode 2015 sampai periode 2017.

Berdasarkan metodenya, jenis penelitian yang digunakan adalah penelitian korelasional dan penelitian komperatif (rasio). Penelitian korelasional adalah suatu penelitian yang dirancang untukn menentukan tingkat hubungan antara variabel modal saham, utang dengan profitabilitas berdasarkan pada koefiesien kolerasi. Sedangkan penelitian komperatif (rasio) adalah penelitian untuk membandingkan antara variable untuk menghasilkan rasio Return on Asset, Capital Adequacy Ratio dan Net Profit Margin.

Definisi operasional variabel penelitian menurut Sugiyono (2016: 38), "Suatu atribut atau sifat atau nilai dari obyek atau kegiatan yang memiliki variasi tertentu yang telah ditetapkan oleh peneliti untuk dipelajari dan kemudian ditarik kesimpulannya."

\section{a. Return on Assets $\left(\mathrm{X}_{1}\right)$}

ROA digunakan untuk menunjukkan kemampuan 
perus ahaan menghasilkan laba dengan menggunakan total aset yang dimiliki. Return on Asset (ROA) menunjukkan kemampuan perusahaan dalam menghasilkan laba dari aktiva yang digunakan. Return on Asset (ROA) merupakan rasio yang terpenting di antara rasio profitabilitas yang ada. Return on Asset (ROA) atau yang sering disebut juga Return on Investment (ROI) diperoleh dengan cara membandingkan laba bersih setelah pajak terhadap total aktiva. Dengan rumus

\section{$R O A=\frac{\text { Laba Bersih Setelah Pajak }}{\text { Total Aset }} X 100 \%$}

b. Capital Adequacy Ratio $\left(\mathrm{X}_{2}\right)$

Menurut $\begin{gathered}\text { Bank } \\ \text { (Nomor }\end{gathered}$
Indonesia 9 9/13/PBI/2007), CAR adalah
penyediaan modal minimum
bagi bank didasarkan pada
risiko aktiva dalam arti luas,
baik aktiva yang tercantum
dalam neraca maupun aktiva
yang bersifat administratif
sebagaimana tercermin pada
kewajiban yang masih bersifat
kontijen dan/atau komitmen
$C A R=\frac{\text { Modal Perusahaan }}{\text { ATMR }} X 100 \%$

c. Net Profit Margin (Y)

Net Profit Margin didefinisikan sebagai berikut, Net Profit Margin adalah merupakan rasio antara laba bersih (Net Profit) yaitu yang disediakan oleh bank bagi pihak ketiga maupun risiko pasar. Maka dapat disimpulkan bahwa CAR adalah rasio kinerja bank untuk mengukur kecukupan modal yang dimiliki bank untuk menunjang aktiva yang mengandung atau menghasilkan risiko, seperti kredit yang diberikan kepada nasabah. Dengan rumus berikut:

penjualan sesudah dikurangi dengan seluruh expense termasuk pajak dibandingkan dengan penjualan. Semakin tinggi NPM, semakin baik operasi suatu perusahaan. Dengan rumus berikut:

\section{Sampel Jenuh/Saturation}

Sampling, karena jumlah subpopulasi kecil, umumnya tidak lebih dari 100. Adapun sampel diambil dengan menggunakan

$$
N P M=\frac{\text { Laba Bersih Setelah Pajak }}{\text { Total Penjualan }} \times 100 \%
$$

teknik purposive sampling, alasan menggunakan teknik purposive sampling adalah karena tidak semua sampel memiliki kriteria yang sesuai dengan yang telah penulis tentukan. 
Uji asumsi klasik yang digunakan ada empat macam, yaitu multikolinieritas, autokorelasi, heteroskedastisitas dan normalitas. Menurut Ghozali (2016: 163) pada model regresi berganda yang bagus, variabel-variabel independen seharusnya tidak berkorelasi satu dengan yang lainnya. Teknik analisis yang akan dipakai dalam penelitian ini adalah teknik analisis regresi linier berganda untuk memperoleh gambaran yang menyeluruh mengenai hubungan antara variabel satu dengan variabel lain.

\section{HASIL DAN PEMBAHASAN}

Dari 43 perusahaan perbankan yang terdaftar di BEI berdasarkan kriteria tersebut diambil 5 perusahaan perbankan yang dijadikan sampel penelitian. Variabel-variabel yang digunakan dalam penelitian ini adalah variabel dependen dan variabel independen. Variabel dependen yang digunakan adalah Net Profit Margin (NPM) dan variabel independen terdiri dari Return on Asset (ROA) dan Capital Adequacy Ratio (CAR).

Data dalam Return on Asset (ROA) (Dalam Jutaan Rupiah)

\begin{tabular}{|l|r|r|r|r|}
\hline \multirow{2}{*}{ Nama Perusahaan Perbankan } & \multirow{2}{*}{ Tahun } & \multicolumn{2}{|c|}{ ROA } & \multicolumn{2}{|c|}{$\%$} \\
\cline { 3 - 5 } & & $\begin{array}{c}\text { Laba Bersih setelah } \\
\text { Pajak }\end{array}$ & Total Aset \\
\hline PT Bank Rakyat Indonesia, tbk & 2015 & 25.410 .788 & 878.426 .312 & 2,89 \\
\hline & 2016 & 26.227 .991 & 1.003 .644 .426 & 2,61 \\
\hline PT Bank Mandiri, tbk & 2017 & 29.044 .344 & 1.126 .248 .442 & 2,58 \\
\hline & 2015 & 21.152 .398 & 910.063 .409 & 2,32 \\
\hline PT Bank Negara Indonesia & 2016 & 14.650 .163 & 1.038 .706 .009 & 1,41 \\
\hline & 2017 & 21.443 .042 & 1.124 .700 .847 & 1,91 \\
\hline PT Bank Danamon Indonesia, tbk & 2015 & 9.140 .532 & 508.595 .288 & 1,80 \\
\hline & 2016 & 11.410 .196 & 603.031 .880 & 1,89 \\
& 2017 & 13.770 .592 & 709.330 .084 & 1,94 \\
\hline PT Bank Tabungan Negara, tbk & 2015 & 2.469 .157 & 188.057 .412 & 1,31 \\
\hline & 2016 & 2.792 .722 & 174.685 .800 & 1,60 \\
& 2016 & 4.150 .170 & 178.257 .092 & 2,33 \\
\hline & 2017 & 1.850 .907 & 171.807 .592 & 1,08 \\
\hline & & 2.618 .905 & 214.168 .479 & 1,22 \\
\hline & 3.027 .466 & 261.365 .267 & 1,16 \\
\hline
\end{tabular}

\section{Data dalam Capital Adequacy Ratio (CAR)}

(Dalam Jutaan Rupiah) 


\begin{tabular}{|c|c|c|c|c|}
\hline \multirow{2}{*}{ Nama Perusahaan Perbankan } & \multirow{2}{*}{ Tahun } & \multicolumn{2}{|c|}{ CAR } & \multirow{2}{*}{$\%$} \\
\hline & & Modal & $\begin{array}{l}\text { Aktiva Tertimbang } \\
\text { Menurut Resiko }\end{array}$ & \\
\hline \multirow[t]{3}{*}{ PT Bank Rakyat Indonesia, tbk } & 2015 & 113.127 .179 & 592.052 .735 & 19,1 \\
\hline & 2016 & 146.812 .590 & 690.049 .947 & 21,3 \\
\hline & 2017 & 167.347 .494 & 763.886 .604 & 21,9 \\
\hline \multirow[t]{3}{*}{ PT Bank Mandiri, tbk } & 2015 & 119.491 .841 & 592.989 .269 & 20,2 \\
\hline & 2016 & 153.369 .723 & 681.305 .785 & 22,5 \\
\hline & 2017 & 170.006 .132 & 746.576 .996 & 22,8 \\
\hline \multirow[t]{3}{*}{ PT Bank Negara Indonesia } & 2015 & 78.438 .222 & 295.327.717 & 26,6 \\
\hline & 2016 & 89.254 .000 & 417.028 .887 & 21,4 \\
\hline & 2017 & 100.903 .304 & 467.504 .308 & 21,6 \\
\hline \multirow[t]{3}{*}{ PT Bank Danamon Indonesia, tbk } & 2015 & 34.214 .849 & 109.212.835 & 31,3 \\
\hline & 2016 & 36.377 .972 & 100.311 .532 & 36,3 \\
\hline & 2017 & 39.172 .152 & 101.375 .374 & 38,6 \\
\hline \multirow[t]{3}{*}{ PT Bank Tabungan Negara, tbk } & 2015 & 13.860 .107 & 129.532 .229 & 10,7 \\
\hline & 2016 & 19.130 .536 & 157.571 .572 & 12,1 \\
\hline & 2017 & 21.663 .434 & 190.407 .847 & 11,4 \\
\hline
\end{tabular}

\begin{tabular}{|c|c|c|c|c|}
\hline \multirow{2}{*}{ Nama Perusahaan Perbankan } & \multirow{2}{*}{ Tahun } & \multicolumn{2}{|c|}{ NPM } & \multirow{2}{*}{$\%$} \\
\hline & & $\begin{array}{c}\text { Laba Bersih Setelah } \\
\text { Pajak }\end{array}$ & Total Penjualan & \\
\hline \multirow[t]{3}{*}{ PT Bank Rakyat Indonesia, tbk } & 2015 & 25.410 .788 & 85.434 .037 & 29,74 \\
\hline & 2016 & 26.227 .991 & 93.995 .015 & 27,90 \\
\hline & 2017 & 29.044 .344 & 102.899 .292 & 28,23 \\
\hline \multirow[t]{3}{*}{ PT Bank Mandiri, tbk } & 2015 & 21.152.398 & 71.570 .127 & 29,55 \\
\hline & 2016 & 14.650 .163 & 76.709 .888 & 19,10 \\
\hline & 2017 & 21.443 .042 & 79.501 .530 & 26,97 \\
\hline \multirow[t]{3}{*}{ PT Bank Negara Indonesia } & 2015 & 9.140 .532 & 36.895 .081 & 24,77 \\
\hline & 2016 & 11.410.196 & 43.768 .439 & 26,07 \\
\hline & 2017 & 13.770 .592 & 48.177 .849 & 28,58 \\
\hline \multirow[t]{3}{*}{ PT Bank Danamon Indonesia, tbk } & 2015 & 2.469 .157 & 28.263.308 & 8,74 \\
\hline & 2016 & 2.792 .722 & 26.554 .900 & 10,52 \\
\hline & 2017 & 4.150 .170 & 25.592 .155 & 16,22 \\
\hline \multirow[t]{3}{*}{ PT Bank Tabungan Negara, tbk } & 2015 & 1.850 .907 & 14.966.209 & 12,37 \\
\hline & 2016 & 2.618 .905 & 17.138.819 & 15,28 \\
\hline & 2017 & 3.027 .466 & 19.271 .582 & 15,71 \\
\hline
\end{tabular}

Hasil nalisis deskriptif diperoleh data sebagai berikut:

\begin{tabular}{|l|r|r|r|}
\hline \multicolumn{3}{|c|}{ Descriptive Statistics } \\
\hline & Mean & Std. Deviation & $\mathrm{N}$ \\
\hline Net Profit Margin & 21.3167 & 7.57185 & 15 \\
\hline Return On Aset & 1.8700 & .57736 & 15 \\
\hline Capital Adequacy Ratio & 22.5200 & 8.17341 & 15 \\
& & & \\
\hline
\end{tabular}


Berdasarkan tabel dapat dilihat bahwa masing-masing variabel memiliki nilai rata-rata yang berada pada angka positif. Bahwa nilai rata-rata Net Profit Margin sebesar 21.3167 lebih besar dari standar devisiasi yaitu 7.57185 maka artinya data stabil, merata, dan tidak terjadi penyimpangan. Hasil nilai ratarata Return on Asset sebesar 1.8700 lebih besar dari standar devisiasi yaitu $\mathbf{0 . 5 7 7 3 6}$ maka artinya data stabil, merata, dan tidak terjadi penyimpangan. Kemudian total nilai rata-rata Capital Adequacy Ratio sebesar 22.5200 lebih besar dari standar devisiasi yaitu $\mathbf{8 . 1 7 3 4 1}$ maka artinya data stabil, merata, dan tidak terjadi penyimpangan.

Untuk

uji

multikolonieritas dapat dilihat pada tabel output coeffisient di bawah ini.

Coefficients $^{\mathbf{a}}$

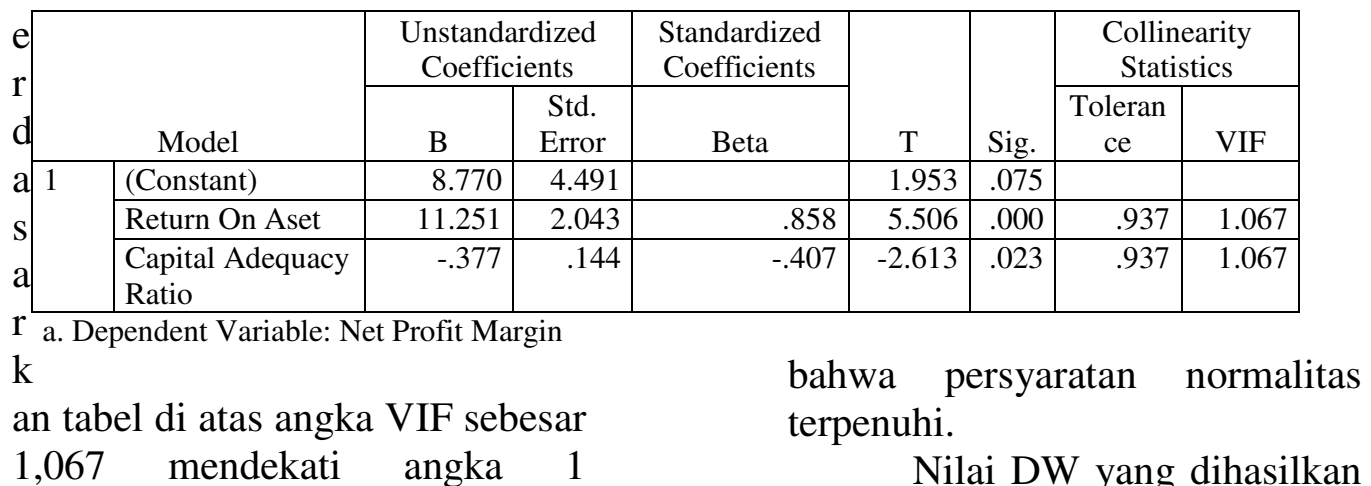
demikian juga angka toeleransi sebesar 0,937 masih di sekitar angka 1. Hal ini menujukkan dugaan tidak adanya multikolonieritas, dalam kasus ini tidak ada hubungan antara variabel $X_{1}$ dengan variabel $X_{2}$. Berdasarkan gambar scaterplot, pencaran data tidak memperlihatkan sebuah pola tertentu, yaitu tidak ada pola menaik ke kanan atas atau pola menurun ke kiri atas atau pola tertentu lainnya. Hal ini menunjukkan bawa model regresi bebas dari heteroskedastisitas. Persyaratan normalitas terpenuhi, jika residual dari distribusi normal maka nilai-nilai sebaran (data gambar noklah-noklah) terletak di sekitar garis lurus atau tidak terpencar jauh dari garis lurus. Oleh karena itu, dapat dikatakan adalah sebesar 1,553 lebih besar dari batas atas atau 1,553 > 1,543 dan lebih kecil dari $4-\mathrm{d}_{\mathrm{u}} \quad(4-$ $1,543=\mathbf{2 , 4 5 7})$ atau DW $<\mathrm{d}<4$ $\mathrm{d}_{\mathrm{u}} \quad(1,543,<\quad 1,553<\quad 2,457)$. Karena nilai DW adalah $\mathbf{1 , 5 3 3}$ berada pada daerah antara $\mathrm{d}_{\mathrm{u}}$ dan 4- $\mathrm{d}_{\mathrm{u}}$, maka hipotesis diterima, yang berarti tidak terjadi autokorelasi.

\section{Uji Signifikansi Parameter Individual (Uji t Parsial)}

Pengujian hipotesis secara parsial adalah iju statistik untuk koefisien regresi yang bertujuan untuk mengetahui pengaruh variabel independen (Return on Asset dan Capital Adequacy Ratio) berpengaruh terhadap variabel dependen (Net Profit Margin). 
dapat dilihat bahwa nilai t hitung

Coefficients $^{\mathrm{a}}$

\begin{tabular}{|c|c|c|c|c|c|c|c|}
\hline \multirow[b]{2}{*}{ Model } & \multicolumn{2}{|c|}{$\begin{array}{l}\text { Unstandardized } \\
\text { Coefficients }\end{array}$} & \multirow{2}{*}{$\begin{array}{c}\begin{array}{c}\text { Standardized } \\
\text { Coefficients }\end{array} \\
\text { Beta }\end{array}$} & \multirow[b]{2}{*}{$\mathrm{T}$} & \multirow[b]{2}{*}{ Sig. } & \multicolumn{2}{|c|}{$\begin{array}{l}\text { Collinearity } \\
\text { Statistics }\end{array}$} \\
\hline & B & $\begin{array}{l}\text { Std. } \\
\text { Error }\end{array}$ & & & & $\begin{array}{c}\text { Toleran } \\
\text { ce }\end{array}$ & VIF \\
\hline (Constant) & 8.770 & 4.491 & & 1.953 & .075 & & \\
\hline Return On Aset & 11.251 & 2.043 & .858 & 5.506 & .000 & .937 & 1.067 \\
\hline $\begin{array}{l}\text { Capital Adequacy } \\
\text { Ratio }\end{array}$ & -.377 & .144 & -.407 & -2.613 & .023 & .937 & 1.067 \\
\hline
\end{tabular}

$h$ a. Dependent Variable: Net Profit Margin

itung $\left(\mathrm{t}_{\mathrm{h}}\right)$ lebih besar dari $\mathrm{t}$ tabel $\left(\mathrm{t}_{\alpha}\right)$ maka $\mathrm{H}_{\mathrm{o}}$ ditolak, ini berarti $\mathrm{H}_{\mathrm{a}}$ diterima. Nilai t hitung Return on Asset berdasarkan dari tabel di atas adalah 5,506. Dari data tersebut dapat dilihat bahwa nilai t hitung bernilai positif maka persamaannya adalah nilai t hitung lebih besar dari nilai $t$ tabel atau $\mathbf{5 , 5 0 6}>\mathbf{1 , 9 8 1}$ dan nilai sig $<\mathbf{0 , 0 0 5}$ atau $0,00<\mathbf{0 , 0 5}$. Dari hasil tersebut dapat disimpulkan bahwa $\mathrm{H}_{\mathrm{o}}$ ditolak dan $\mathrm{H}_{\mathrm{a}}$ diterima. Hal ini berarti bahwa Return on Asset berpengaruh signifikan terhadap Net Profit Margin.

Nilai - $t$ hitung $\left(t_{h}\right)$ lebih kecil dari -t tabel $\left(\mathrm{t}_{\alpha}\right)$ maka $\mathrm{H}_{\mathrm{o}}$ ditolak, ini berarti $\mathrm{H}_{\mathrm{a}}$ diterima. Nilai t hitung Capital Adequacy berdasarkan dari tabel di atas adalah $(-\mathbf{2 , 6 1 3 )}$. Dari data tersebut bernilai negatif maka persamaannya adalah nilai t hitung lebih kecil dari nilai t tabel $\mathbf{- 2 , 1 6 0}$ atau -2,613 $<-\mathbf{2 , 1 6 0}$ dengan nilai Sig $<\mathbf{0 . 0 5}$ atau $0,023<0,05$ Dari hasil tersebut dapat disimpulkan bahwa $\mathrm{H}_{\mathrm{o}}$ ditolak dan $\mathrm{H}_{\mathrm{a}}$ diterima. Hal ini berarti bahwa Capital Adequacy Ratio berpengaruh terhadap Net Profit Margin dengan arah negatif, yaitu jika nilai CAR ditingkatkan maka nilai NPM turun atau jika nilai CAR turun maka nilai NPM naik.

\section{Uji Signifikansi Simultan (Uji Statistik F)}

Uji $F$ adalah uji statistik yang dilakukan untuk koefisien regresi yang simultan atau serentak secara bersama sama terhadap variabel

\begin{tabular}{|l|l|r|r|r|r|r|}
\hline \multicolumn{7}{|c|}{ ANOVA $^{\mathbf{a}}$} \\
\hline \multirow{3}{*}{ Model } & Sum of Squares & Df & Mean Square & F & Sig. \\
\hline 1 & Regression & 583.472 & 2 & 291.736 & 15.972 & $.000^{\mathrm{b}}$ \\
\cline { 2 - 8 } & Residual & 219.188 & 12 & 18.266 & & \\
\cline { 2 - 8 } & Total & 802.660 & 14 & & & \\
\hline
\end{tabular}

a. Dependent Variable: Net Profit Margin

b. Predictors: (Constant), Capital Adequacy Ratio, Return On Aset

Nilai F berdasarkan tabel di atas adalah 15,972. Dapat dilihat bahwa nilai $\mathrm{F}$ dari tabel tersebut lebih besar dari nilai $\mathrm{F}$ tabel atau 15,972 > 3,806 dan nilai probabilitas lebih kecil dari
0,05 atau $0.005<0,05$. Maka dapat disimpulkan bahwa kedua variabel bebas (Return on Asset dan Capital Adequacy Ratio) secara simultan berpengaruh 
ROA terhadap NPM

\begin{tabular}{|c|c|c|c|c|}
\hline \multicolumn{5}{|c|}{ Model Summary $^{b}$} \\
\hline Model & $\mathrm{R}$ & R Square & Adjusted R Square & $\begin{array}{l}\text { Std. Error of the } \\
\text { Estimate }\end{array}$ \\
\hline 1 & $.756^{\mathrm{a}}$ & .572 & .539 & 5.14330 \\
\hline
\end{tabular}

a. Predictors: (Constant), Return On Aset

b. Dependent Variable: Net Profit Margin

Berdasarkan hasil perhitungan pada analisis regresi dan diubah dalam bentuk pesentase maka $\mathrm{R}^{2}$ ( $\mathrm{R}$ square) data penelitian adalah sebesar $57.2 \%$. Dapat diartikan bahwa Return on Asset berkontribusi sebesar $57.2 \%$ terhadap Net Profit Margin perbankan. Sedangkan sisanya $(42,3 \%)$ dipengaruhi oleh variabel lain di luar model regresi ini.

\section{Hasil Uji Koefisien Determinasi}

CAR terhadap NPM

\begin{tabular}{|c|c|c|c|c|}
\hline \multicolumn{5}{|c|}{ Model Summary } \\
\hline Model & $\mathrm{R}$ & R Square & Adjusted R Square & $\begin{array}{l}\text { Std. Error of the } \\
\text { Estimate }\end{array}$ \\
\hline 1 & $.192^{\mathrm{a}}$ & .037 & -.037 & 7.71091 \\
\hline
\end{tabular}

a. Predictors: (Constant), Capital Equacy Ratio

b. Dependent Variable: Net Profit Margin

Berdasarkan hasil

perhitungan pada analisis regresi dan diubah dalam bentuk pesentase maka $\mathrm{R}^{2}$ ( $\mathrm{R}$ square) data penelitian adalah sebesar $3.7 \%$. Dapat diartikan bahwa Capital Adequacy Ratio berkontribusi

sebesar 3,7 \% terhadap Net Profit Margin perbankan. Sedangkan sisanya $(96,3 \%)$ dipengaruhi oleh variabel lain di luar model regresi ini.

Hasil Uji Koefisien Determinasi

ROA dan CAR terhadap NPM

\begin{tabular}{|c|c|c|c|c|}
\hline \multicolumn{5}{|c|}{ Model Summary $^{b}$} \\
\hline Model & $\mathrm{R}$ & R Square & Adjusted R Square & $\begin{array}{l}\text { Std. Error of the } \\
\text { Estimate }\end{array}$ \\
\hline 1 & $.853^{\mathrm{a}}$ & .727 & .681 & 4.27383 \\
\hline
\end{tabular}

a. Predictors: (Constant), Capital Adequacy Ratio, Return On Aset

b. Dependent Variable: Net Profit Margin

Berdasarkan hasil

perhitungan pada analisis regresi berganda dan diubah dalam bentuk pesentase maka $\mathrm{R}^{2}(\mathrm{R}$ square) data penelitian adalah sebesar $72,7 \%$. Dapat diartikan bahwa Return on Asset dan Capital Adequacy Ratio berkontribusi sebesar 72,7 \% terhadap Net Profit Margin perbankan. Sedangkan sisanya $(27,3 \%)$ dipengaruhi oleh variabel lain di luar model regresi ini.

\section{KESIMPULAN}

Penelitian ini bertujuan untuk mengetahui pengaruh 
Return on Asset dan Capital Adequecy Ratio terhadap kinerja kuangan pada perusahaan perbankan di Indonosia yang terdaftar di BEI tahun 20152017. Hasil pengujian hipotesis menggunakan analisis regresi berganda adalah sebagai berikut:

1. Hasil penelitian menunjukkan bahwa tilai $\mathrm{t}$ hitung $\left(\mathrm{t}_{\mathrm{h}}\right)$ lebih besar dari $\mathrm{t}$ tabel $\left(\mathrm{t}_{\alpha}\right)$ maka $\mathrm{H}_{\mathrm{o}}$ ditolak, ini berarti $\mathrm{H}_{\mathrm{a}}$ diterima. Nilai $\mathrm{t}$ hitung Return on Asset berdasarkan dari tabel adalah 5,506. Dari data tersebut dapat dilihat bahwa nilai $\mathrm{t}$ hitung bernilai positif maka persamaannya adalah nilai $\mathrm{t}$ hitung lebih besar dari nilai $\mathrm{t}$ tabel atau 5,506 > 1,981 dan nilai sig $<\mathbf{0 , 0 0 5}$ atau $0,00<$ 0,05. Dari hasil tersebut dapat disimpulkan bahwa $\mathrm{H}_{\mathrm{o}}$ ditolak dan $\mathrm{H}_{\mathrm{a}}$ diterima. Hal ini berarti bahwa Return on Asset berpengaruh signifikan terhadap Net Profit Margin.

2. Hasil penelitian menunjukkan nilai $\mathrm{t}$ hitung lebih kecil dari nilai t tabel $\mathbf{2 , 1 6 0}$ atau $-\mathbf{2 , 6 1 3}<-\mathbf{- 2 , 1 6 0}$ dengan nilai Sig $<\mathbf{0 . 0 5}$ atau $\mathbf{0 , 0 2 3}<0,05$. Dari hasil tersebut dapat disimpulkan bahwa $\mathrm{H}_{\mathrm{o}}$ ditolak dan $\mathrm{H}_{\mathrm{a}}$ diterima. Hal ini berarti bahwa Capital Adequacy Ratio berpengaruh terhadap Net Profit Margin dengan arah negatif, yaitu jika nilai CAR ditingkatkan maka nilai NPM turun atau jika nilai CAR turun maka nilai NPM naik.

3. Hasil penelitian menunjukkan bahwa Return on Asset dan Capital

\begin{abstract}
Adequacy Ratio secara simultan berpengaruh terhadap Net Profit Margin, nilai $\mathrm{F}$ berdasarkan hasil penelitian adalah $\mathbf{1 5 , 0 7 2}$ lebih besar dari nilai $\mathrm{F}$ tabel $(\mathbf{3 , 8 0 6})$ dan nilai probabilitas lebih kecil dari nilai signifikansi atau $\mathbf{1 5 , 0 7 2}$ >0,05. Maka dapat disimpulkan bahwa kedua variabel bebas (Return on Asset dan Capital Adequacy Ratio) secara simultan berpengaruh signifikan terhadap variabel Net Profit Margin.
\end{abstract}

\section{REFERENSI}

Fahmi, Irham. 2014. Managemen Keuangan. Jakarta: Mitra Wacana Media.

Ghozali, Imam. 2016. Aplikasi Analisis Multivariete dengan Progam IBM SPSS 23. Edeisi 8. Cetakan 8. Semarang: Universitas Diponegoro.

Hamdi, Rismon dan Henny Setyo Lestai. 2015. Pengaruh Rasio Solvabilitas dan Inflasi Terhadap Kinerja keuangan pada Bank Umum Swasta Nasional Devisa yang terdaftar di Bursa Efek Indonesia. Surabaya: STIE Perbanas Surabaya.

Hasibuan, H. Malayu 2015. DasarDasar Perbankan. Jakarta: PT Bumi Askara.

Hery. 2014. Analisis Laporan Keuangan. Cetakan Ke-3. Jakarta: PT Grasindo.

Ikatan Akuntansi Indonesia. 2015. Standar Akuntansi Keuangan. Jakarta: Salemba Empat

Kasmir. 2016. Analisis Laporan Keuangan. Cetakan Ke-9. 
Jakarta: PT Raja Grafindo Persada.

Munawir. 2014. Analisis Laporan Keuangan. Edisi 4. Cetakan 16. Yogyakarta: Liberty.

Nurul Hidayati. 2013. Analisis Kinerja Keuangan Antara PT Bank Negara Indonesia tbk dan PT Bank Internasional Indonesia tbk di Bursa Efek Indonesia. Surabaya: STIESIA Surabaya.

Silaen, Sofar dan Widiyono. 2018. Metode Penelitian Sosial Untuk Penulisan Skripsi dan Tesis. Jakarta: In Media.

Sugiono, Arief dan Edy Untung. 2016.

Panduan Praktis Dasar Analisa Laporan Keuangan. Jakarta: PT Grasindo.

Sugiyono. 2016. Metode Penelitian Kuantitatif, Kualitatif dan $R \& D$. Bandung: CV Alfabeta.

Sugiarto, Agung. 2012. "Adopsi Internet Banking Bagi Keungguka Performa Perbankan". Jakarta: Jurnal Dinamika Akuntansi

Taswan. 2013. Akutansi PerbankanTransaksi dalam Valuta Rupiah. $\quad$ Edisi Ke-3. Yogyakarta: UPP STIM YKPN. 